\title{
A Systematic Literature Review of Quantitative Research Islamic Pilgrimage Tourism Research Era 2000 to 2021
}

Ras Afirina Mohd Radzi, Siti Rahayu Hussin, Suhaimi Ab Rahman, Zulhamri Abdullah

To Link this Article: http://dx.doi.org/10.6007/IJARBSS/v11-i10/11048

DOI:10.6007/IJARBSS/v11-i10/11048

Received: 07 August 2021, Revised: 27 August 2021, Accepted: 10 September 2021

Published Online: 01 October 2021

In-Text Citation: (Radzi et al., 2021)

To Cite this Article: Radzi, R. A. M., Hussin, S. R., Rahman, S. A., \& Abdullah, Z. (2021). A Systematic Literature Review of Quantitative Research Islamic Pilgrimage Tourism Research Era 2000 to 2021. International Journal of Academic Research in Business and Social Sciences, 11(10), 644-658.

Copyright: (C) 2021 The Author(s)

Published by Human Resource Management Academic Research Society (www.hrmars.com)

This article is published under the Creative Commons Attribution (CC BY 4.0) license. Anyone may reproduce, distribute, translate and create derivative works of this article (for both commercial and non-commercial purposes), subject to full attribution to the original publication and authors. The full terms of this license may be seen

at: http://creativecommons.org/licences/by/4.0/legalcode

Vol. 11, No. 10, 2021, Pg. 644 - 658

Full Terms \& Conditions of access and use can be found at http://hrmars.com/index.php/pages/detail/publication-ethics 


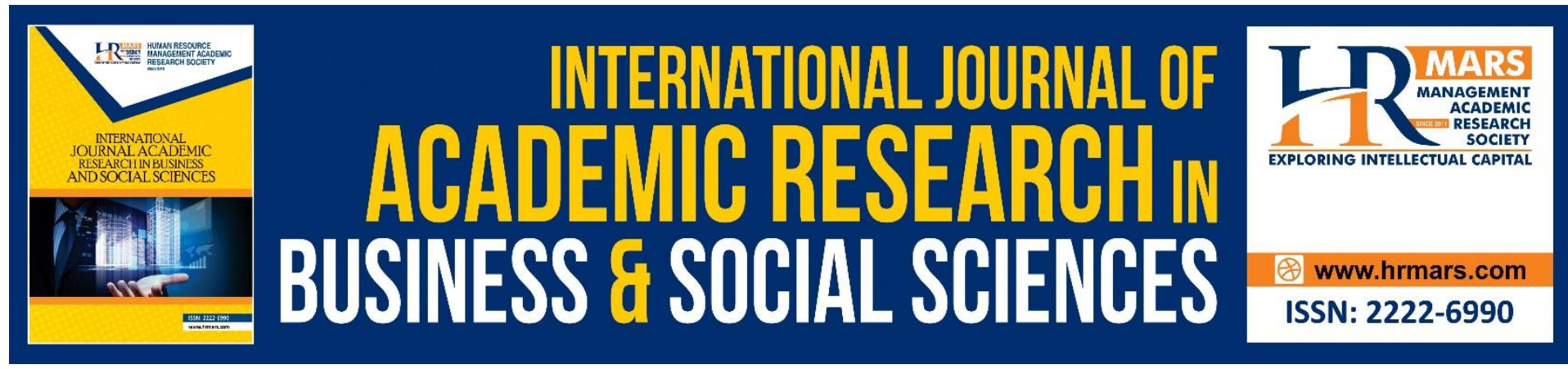

\title{
A Systematic Literature Review of Quantitative Research Islamic Pilgrimage Tourism Research Era 2000 to 2021
}

\author{
Ras Afirina Mohd Radzi ${ }^{1}$, Siti Rahayu Hussin², Suhaimi Ab \\ Rahman $^{3}$, Zulhamri Abdullah ${ }^{4}$
}

${ }^{1}$ Department of Marketing and Management, School of Business and Economics, Universiti Putra Malaysia 43400 UPM Serdang, Selangor, ${ }^{2}$ Department of Marketing and Management, School of Business and Economics, Universiti Putra Malaysia 43400 UPM Serdang, Selangor ${ }^{3}$ Department of Marketing and Management, School of Business and Economics, Universiti Putra Malaysia 43400 UPM Serdang, Selangor, ${ }^{4}$ Department of Communication, Faculty of

Modern Language and Communication, Universiti Putra Malaysia 43400 UPM Serdang, Selangor

\begin{abstract}
Purpose: The aim of this study is to examine and systematically review of the existing literature on Islamic pilgrimage tourism towards crisis. Furthermore, this study seeks to explore the systematic literature to deliver the trends and categorization regarding the recent publication of Islamic pilgrimage. Design/methodology/approach - Preferred Reporting Items for Systematic Review was adopted for current systematic literature review. Search strategy was applied on different databases including Taylor \& Francis, Dimensions.ai, Google Scholar, Scopus and the collection of articles were selected from high impact journals published between 2000 to 2021. The search item was classified according to inclusion and exclusion criteria. Findings - In this selected quantitative study, around 49 articles were extracted in total, out of 129 papers were collected. All of the articles selected were from high impact journals. The analyzed data was resulted in map of the research field, which was presented under perspectives: geographical location of authors, types of study, number of citations, prolific journals, extracted themes from various studies, sample size and method of analysis. Moreover, the primary research focuses on Islamic pilgrimage tourism. The majority of the studies were focused on Islamic pilgrimage. Research limitations/implications -The study identifies as 'stock take' of Islamic pilgrimage studies as a spiritual journey that could be strategically used by research article. Articles that include in this systematic literature review only include from high ranked journal, which may perceive as a limitation. Other limitation is the study limited to four different databases and articles that are written in English. Practical implications - Future researchers can review the result of the current systematic literature review to set the direction of their study in the area of Islamic pilgrimage tourism. These results can be used by researchers to widen the knowledge about extent of research that conducted in this area. Managerial can develop policies based on Islamic pilgrimage. Originality/value - This review provides a strong contribution to Islamic pilgrimage.
\end{abstract}


Keywords: Islamic Pilgrimage, Religious Tourism, During and Post-Pandemic Tourism, Systematic Literature Review

\section{Introduction}

Tourism is an activity that consists essentially of temporary (Ritonga et al., 2018). Various of activity and attractions that marketers offer products and services on the tourism market and achieving numerous financial benefits. Tourism is the largest sector where customers are highly involved. There are many types of tourism and pilgrimage tourism is one of the niche markets in the tourism sector. Pilgrimage tourism comprises people to travel for religious purposes and religious beliefs. There are multiple religious sites in the world such as temples, mosques, and churches that attract a large number of tourists worldwide. As the United World Tourism Organization (2017) said that religious tourism is less affected by trends and economic crises than other types of tourism. Also noted that Saudi Arabia received more than 23 million trips in 2014 and $24.3 \%$ of the trips accounted for religious purposes.

This study was conducted to fill the gap of limited research on Islamic pilgrimage tourism. The sub-tourism of Islamic pilgrimage tourism towards crisis is still lacking from both practitioners and researchers. The lack of relevance of traditional literature reviews has proven to be outdated as they usually used a personal and usually subjective methodology. Specific philosophies of literature review that provide a transparent process were used to fill the gap in this research area. A systematic review aims to explore the specific research contribution in the Islamic pilgrimage area. The results are descriptively presented and discussed in a later section. This research aiming to explore the theoretical fundamental of Islamic pilgrimage tourism research and identify their structure, the systematic literature review was performed.

Hence, this study seeks to address the issue raises for a systematic literature review of papers on Islamic pilgrimage tourism that have been published only recently. To fill this gap, a systematic literature review was applied. After article collection, the article continues by categorising the data found according to specific criteria. After a systematic literature review, the paper concludes with findings, discussion, limitations and suggestions for future research.

Pilgrimage tourism is defined as visiting and perform the ritual at sacred places, participate in and fulfil religious needs in tourism form. A tourist with religious belief and to see local pilgrimage destination attraction while during the pilgrimage. Rinschede (1992) elaborate that tourist behaviour including travel patterns (season, time, festive), transport of choice and demand. Spiritual destination visitors tend to travel in large groups or with family. Pilgrimage trips are highly seasonal, influenced by climate, holidays such as the end of the year, festive season and work schedules. For most pilgrimage sites, there are socio-demographic differences in terms of their needs and wants on tourism products. Another factor that influences the visitation such religious reasons; repent from sin, connection with the site, increasing religious belief and fulfilling religious duties. The history of the Islamic pilgrimage to modern pilgrimage will be discussed in a further section.

\section{Historical of Pilgrimage to Modern Islamic Pilgrimage Tourism}

Pilgrimage tourism is the oldest form of tourism and date back thousands of years ago (Tala, 2018). The journey to the sacred place from the past such as visiting settlements or mountains did not have in today logistic support the motivation to go is the same. Islamic pilgrimage 
tourism such as Hajj is the most important pilgrimage in Islam. It is an obligatory duty for all Muslims who can afford Mecca. It takes place during the month of Dzul-hijjah. Hajj is strict with quotas and rituals. While Umrah, is similar to Hajj pilgrimage but it is not a requirement and be performed at any time. Many Muslims perform Umrah before Hajj to prepare themselves for Hajj.

According to Qur'an, Muslims should travel with purpose and Islamic pilgrimage both Hajj and Umrah means dedicating purpose to God. According to Islamic history, Prophet Ibrahim and his son Ismail constructed Kaaba as a holy shrine. The instruction was from angel Jibrail or Gabriel. After fulfilling seven rounds of anticlockwise direction around the Kaaba, Muslim pilgrims should run back and forth seven times to complete Sai's between two hills al-Safa and al-Marwah. The story behind this was previously, Prophet Ibrahim left his wife Hajar and his son alone. Hajar went in search of water between al-Safa and al-Marwah, where now pilgrims drink from the Well of Zamzam. After that, pilgrims head to a hill of Arafah (outside Mecca) to pray and meditate from noon to sunset. Prophet Muhammad delivered his sermon at this place and many people believe that God answers their prayer. After the hill of Arafah, pilgrims go to Muzdalifah where pilgrim will collect stones and thrown at the three pillars of Aqaba in Mina that symbolises stoning of Satan. At the end of the Hajj, thousands of sacrificial animals such as sheep and goats are slaughtered in Mina. Once it is completed, pilgrims will return to Mecca and continue to do tawaf and Sa'ie again. Pilgrims will stay in the tent city in Mina during the period in Mecca. If there is any violation is made during Hajj, pilgrims will pay a fine called a "damm". Some prohibited activities include cutting hair and applying perfumes.

Mecca is not only a sacred place in Islam, but Jerusalem was also the original Kiblah (direction towards the west for prayer) before it changed to Mecca. Jerusalem is not only for Islam, but it is also sacred for Christianity and Judaism. For Christians, Jerusalem was the rebirth of Jesus. Jerusalem was revered because it was Muslim tradition and Muhammad travelled to Jerusalem by night and ascended from there to heaven (Heidari et al., 2018)

The modern pilgrimage has more benefit due to the existence of an electronic form of pilgrimage tool as guidance of smartphone apps for both Hajj and Umrah pilgrimage. Previously, Islamic pilgrims travel to Mecca via sea but it is now changing to air travel that made it easier for Muslims to reach Mecca. Tour companies throughout the world are very popular as it provides the whole package from transportation, accommodation, meals and support.

There has been discussion about pilgrimage tourism. For example, Qurashi (2017) said that Muslim pilgrims come from many countries and generates income for Saudi Arabia for the past 30 years with approximately USD16 billion. Saudi Arabia not only improves the facilities but also invest gain maximum economic advantage from religious tourism. Although development is good for tourist, Qurashi (2017) argue that pilgrims will undertake tourism experience such as sightseeing, shopping, that apart from devotional aspects, nearly the same a normal tourist does.

Spiritual, religious and pilgrimage tourism may seem to be backwards but the demand for Islamic pilgrimage, in particular, is increasing (Heidari et al., 2018). Moreover, there is a lot involved in pilgrimage tourism such as accommodation, transport, excursion, and also 
restaurants, handicraft, food production, and other components that support Islamic pilgrimage tourism. Marketers or tour operators are expected to provide various amenities for pilgrims.

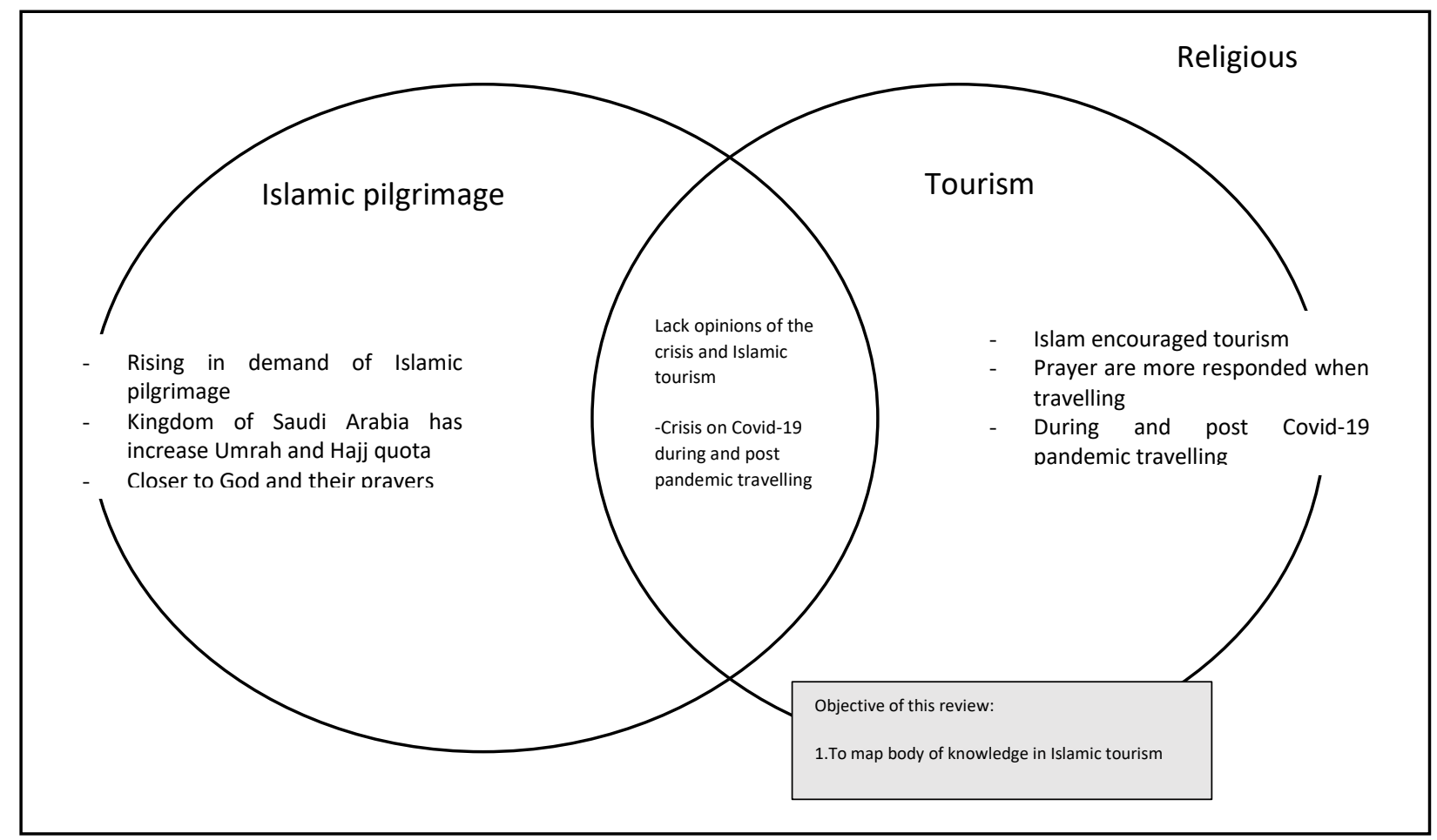

Fig 1. Review aims

The SARS Cov-2 is devastating for the economic and social especially for Islamic pilgrimage tourism as pilgrimages involved gatherings that could spread Covid-19. It forces Mecca and the whole of Saudi Arabia to cancel Umrah and Hajj in 2020. The only exceptions for Umrah and Hajj are pilgrims that are already in the country and limit the quota for Hajj. Saudi officials must meet the serious challenge when it comes to understanding the impact of limiting Umrah and Hajj gatherings.

The current study will explore and develop a systematically literature review methodology to track Islamic pilgrimage studies globally. The aim of this study as follows;

1) To examine and systematically review of the existing literature on Islamic pilgrimage tourism towards crisis

2) To explore the systematic literature to deliver the trends and categorization regarding the recent publication of Islamic pilgrimage.

We use Islamic pilgrimage in the English peer-reviewed literature as a proxy sample or indicator of identity, characterized and compared to see whether Islamic pilgrimage tourism occur. Having a systematic literature review will help us to 'stock take' undocumented and documented Islamic studies outside the scientific literature. Peer-reviewed studies, however, represent a widely accepted and scientifically rigorous source for rapid and standardized assessment, forming the basis of numerous scientific syntheses. Methodological and data collection is explained in a later section.

\section{Methodology}


The current study uses a systematically literature review approach that comprises search strategy such as identifying suitable studies to include, description of methods used, criteria for determination of independent findings, details of study coding categories, statistical procedures, treatment of quantitative research, period, acknowledgements, statement concerning conflict of interest, references and tables. Although the approach is popular among health sciences research, it is less seen in tourism studies but offers a considerable amount in a field characterized by an exploding body of research but seemingly lacking means to keep track of the latest update.

\section{Document Selection}

A keyword search was performed using the search engine in different databases using English key topic terms "Islamic pilgrimage" AND "tourism". Taylor \& Francis, Dimensions.ai, Google Scholar and Scopus were selected as these databases are the most used, powerful, current and comprehensive search engines available for analysis of interdisciplinary, peer-reviewed literature (Kitchenham et al., 2008). The purpose of this study was to explore the findings of studies reported and published between 2000 to 2021 on Islamic pilgrimage tourism in the context of tourism. Second, comprehensive search databases were developed of quantitative and qualitative research studies published in reputable journals. The study can be considered as the second step toward a systematic literature review on Islamic pilgrimage tourism. Documents not in English, outside of the search period and other than articles and reviews were excluded. The search generated 49 papers, which were then screened according to the following inclusion/exclusion criteria in Table 1. In certain cases, the cursory or in-depth fulltext review was conducted to assess suitability. Excluded articles were categorized to allow descriptive evaluation of documents not included in the final review.

Articles were selected to identify the reporting or discussing Islamic pilgrimage tourism. United World Tourism Organization were used to guide classification, inclusion/exclusion criteria and sub-categorization of documents. Herein, Islamic pilgrimage, a summary of definition and classification used for document selection is provided in Table 1.

Table 1: Inclusion and Exclusion Criteria

\begin{tabular}{|l|l|l|}
\hline Parameter & Inclusion criteria & Exclusion criteria \\
\hline Articles & $\begin{array}{l}\text { Islamic pilgrimage tourism } \\
\text { and Islamic religious travel } \\
\text { was used as the main search } \\
\text { of journal articles }\end{array}$ & $\begin{array}{l}\text { Any articles not based on } \\
\text { Islamic pilgrimage, research } \\
\text { thesis and other reports }\end{array}$ \\
\hline Journals & $\begin{array}{l}\text { Include high indexed } \\
\text { journals }\end{array}$ & $\begin{array}{l}\text { Unpublished and published } \\
\text { journal in low impact factor }\end{array}$ \\
\hline The period & $\begin{array}{l}\text { Articles that are between } \\
2000 \text { to 2021 }\end{array}$ & Studies published before \\
\hline The study type & $\begin{array}{l}\text { Quantitative and qualitative } \\
\text { studies }\end{array}$ & $\begin{array}{l}\text { Other than quantitative and } \\
\text { qualitative studies }\end{array}$ \\
\hline The settings & $\begin{array}{l}\text { Articles that carried out on } \\
\text { Islamic pilgrimage in English } \\
\text { language }\end{array}$ & $\begin{array}{l}\text { Studies that were done on } \\
\text { other language and done on } \\
\text { other religion pilgrimage }\end{array}$ \\
\hline
\end{tabular}




\section{Results}

For better understanding, articles were reviewed many times on the topical, method and types of analysis. Total of 129 papers for potential relevance to the research problem in an initial search. Total of 108 papers excluded at this stage because the type of study were reviews, books, report papers and was also excluded because these were not relevant inclusion criteria. Full text of potentially eligible papers $n=49$ paper then assessed and were finally selected for systematic review which was fulfilling the selection criteria as given in in Fig. 2. Fig. 2 provides a visual view of the flow chart from identification, screening, eligibility and included. Findings and discussion in a later section.
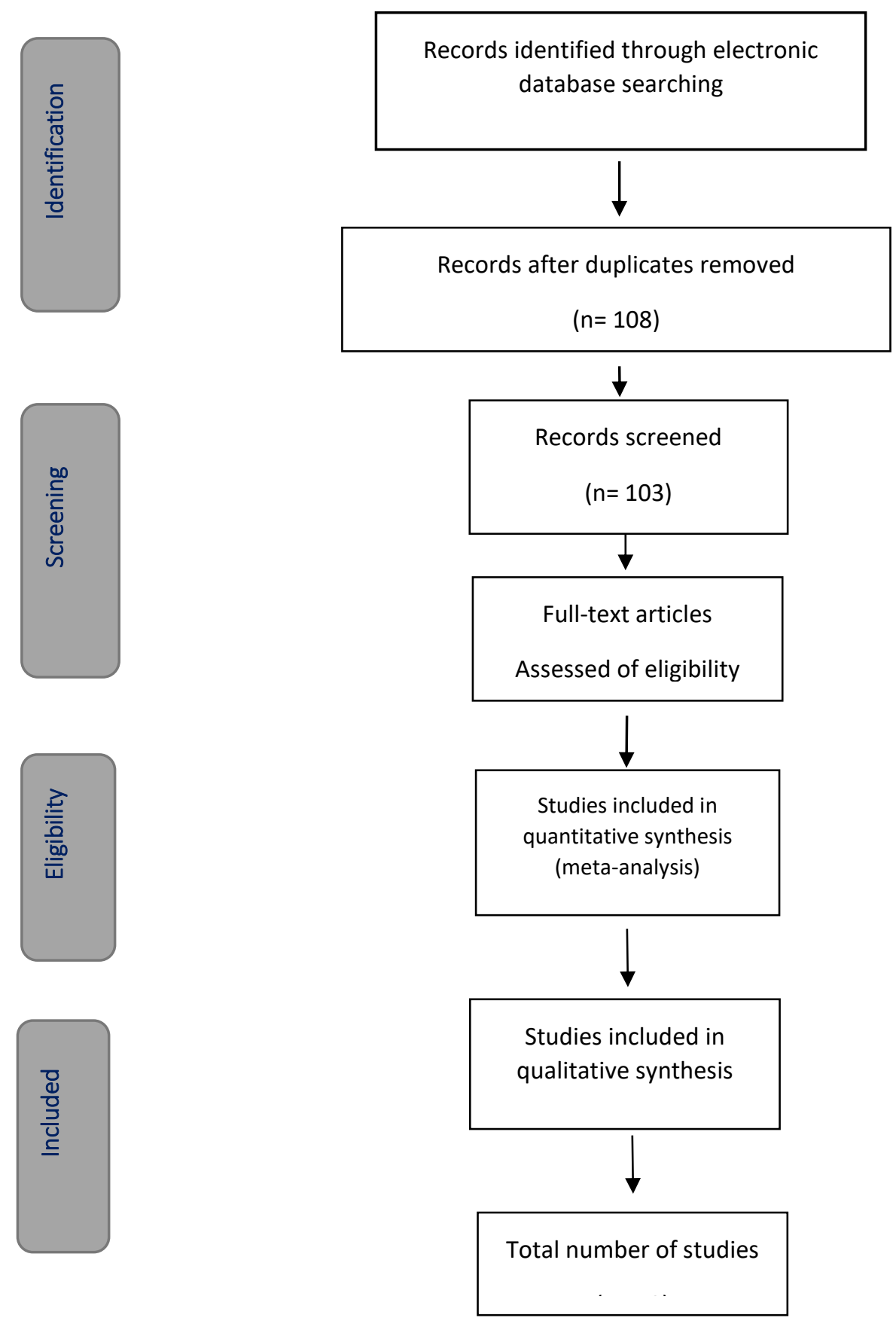

Fig 2: A PRISMA Flowchart

Process of systematic literature review 
Summary of the systematic literature review was created in Microsoft Excel software. In which, all 49 studies were tabulated, read, compared, and analyse. The profile of all 49 studies was presented in Table 2, Table 3, and Table 4. As shown in Table 2, the number of research publications on Islamic pilgrimage has increased significantly by the year 2010. The trend of Islamic pilgrimage was consistent with the development of Islamic pilgrimage research in tourism, as were discussed in an earlier introduction. These studies were ranked according to inclusion criteria that relevant to the review. Some evaluation is considered as follows; the extend the concept of Islamic pilgrimage is explore and examine that include pilgrimage outside of Umrah and Hajj; emphasizes in Islamic pilgrimage; an explanation for Islamic pilgrimage on travel risks, travel behaviour and travel motivation. Summarizes of research topics, research aims, geographical locations, samples, Islamic pilgrimage related findings and detailed explanations is available in Table 2, Table 3 and Table 4. Subsequently, descriptive content analysis was coded in each category and abstracted into constructs and themes. Research gaps and patterns were explored and quantified in the following discussion.

Table 4 summarizes the tourist samples, geographical locations, and tourism settings considered in the extracted studies. The Middle East were the most researched geographical location ( 27 studies), followed by Malaysia ( 6 studies). A majority method of analysis chooses qualitative method by interview (19 studies), followed by quantitative (16 studies) and others (14 studies). These studies were recent, mostly published within the last twenty years.

The research topics across the extracted studies were highly diverse. Islamic pilgrimage (38 studies) was the most researched topic, followed by satisfaction ( 7 studies), service and motivation ( 6 studies), health (5 studies), loyalty and marketing (4 studies). While other 21 studies have considered Islamic pilgrimage as the main subject of investigation, this is not to say that the remaining studies have not investigated Islamic pilgrimage tourism. Rather, this handful of studies has devoted to the investigation of Islamic pilgrimage and its dimensions whereas others examined Islamic pilgrimage less explicitly or indirectly. For instance, many studies considered Islamic pilgrimage as one of the variables when examining tourist motivation, intention to visit, socio-cultural impacts, just to name a few. The research topics investigated in these studies were illustrated in Table 4.

Table 4 summarize the research paradigm. As inclusion criteria, a total number of 49 papers were included for this systematic literature review. We selected 25 papers are from the Middle East. Six papers were included based on Malaysia. Other studies that fulfil the inclusion criteria were included from Indonesia, Turkey and Saudi Arabia. Studies from 2000 to 2021 were conducted on different authors on an Islamic pilgrimage.

These studies were selected from the specific journals which met the inclusion and exclusion criteria set in this paper. Five studies were taken from the International Journal of Religious Tourism and Pilgrimage. Three articles from Tourism Management and three from the Journal of Islamic Marketing. Other journals are also taken into consideration due to their impact factor as shown in Table 3.

A sample comes from Umrah and Hajj pilgrim respondents. Researchers deal with diverse consumer groups (e.g working adults, students, women). In terms of several samples, 18 studies have less than 100 samples, five studies have 100-499 samples and nine studies have more than nine samples. 
Methods of analysis, on the other hand, factor analysis, structural equation modelling and partial least square were the main methods of analysis used in quantitative study research. As for qualitative, most of the studies did not specified method analysis. Only one qualitative study mentioned that thematic analysis is used. They include the theory of reasoned action, the theory of planned behaviour, service quality SERVQUAL, Stimulus-Organism-Response theory and Push and Pull motivation.

Table 2

Literature profiles for disciplines and publication years

\begin{tabular}{|l|l|l|l|l|l|}
\hline $\begin{array}{l}\text { Discipline (No. of } \\
\text { journals) }\end{array}$ & No of studies & $\begin{array}{l}\text { Year 2000 - } \\
\mathbf{2 0 0 5}\end{array}$ & $\begin{array}{l}\text { Year 2006 } \\
-\mathbf{2 0 1 0}\end{array}$ & $\begin{array}{l}\text { Year } \\
\mathbf{2 0 1 1} \\
\mathbf{2 0 1 5}\end{array}$ & $\begin{array}{l}\text { Year } \\
\mathbf{2 0 1 6} \\
\mathbf{2 0 2 1}\end{array}$ \\
\hline $\begin{array}{l}\text { Tourism, Leisure, } \\
\text { religion and } \\
\text { Hospitality }\end{array}$ & 21 & 0 & 0 & 7 & 11 \\
\hline Religion & 7 & 0 & 1 & 0 & 4 \\
\hline $\begin{array}{l}\text { Business and } \\
\text { marketing }\end{array}$ & 10 & 0 & 1 & 3 & 5 \\
\hline Health & 5 & 0 & 1 & 2 & 2 \\
\hline $\begin{array}{l}\text { Information } \\
\text { Technology }\end{array}$ & 1 & 1 & 0 & 0 & 0 \\
\hline Anthropology & 4 & 0 & 0 & 1 & 3 \\
\hline Engineering & 2 & 0 & 1 & 0 & 1 \\
\hline Geography & 3 & 0 & 0 & 1 & 1 \\
\hline
\end{tabular}

Table 3

Top journals for Islamic Tourism Research

\begin{tabular}{|l|l|l|}
\hline Top journals & $\begin{array}{l}\text { Number } \\
\text { of articles }\end{array}$ & $\begin{array}{l}\text { Impact } \\
\text { Factor }\end{array}$ \\
\hline Current Issues in Tourism & 1 & Q1 \\
\hline Asia pacific journal of tourism research & 1 & Q1 \\
\hline Journal of travel and tourism marketing & 2 & Q1 \\
\hline south African family practice & 1 & Q2 \\
\hline Tourism management perspectives & 2 & Q1 \\
\hline The Service Industries Journal & 1 & Q1 \\
\hline Tourism Management & 3 & Q1 \\
\hline tourism review & 1 & Q1 \\
\hline Journal of Tourism and Cultural Change & 1 & Q1 \\
\hline Tourism Recreation Research & 1 & Q2 \\
\hline Tourism Analysis & 1 & Q2 \\
\hline International Journal of Religious Tourism and Pilgrimage & 5 & Q1 \\
\hline Indonesia and the Malay world & 1 & Q2 \\
\hline international journal tourism policy & 1 & Q4 \\
\hline Arabica 27 & 1 & Q2 \\
\hline
\end{tabular}




\begin{tabular}{|l|l|l|}
\hline Religions & 2 & Q1 \\
\hline Global Journal al-Thaqafah & 1 & Q4 \\
\hline Research in International Business and Finance & 1 & Q1 \\
\hline Journal of Islamic Marketing & 3 & Q2 \\
\hline marketing theory & 1 & Q1 \\
\hline Journal of International Development and Cooperation & 1 & Q4 \\
\hline mental, health, religion and culture & 1 & Q3 \\
\hline Travel Medicine and Infectious Disease & 1 & Q1 \\
\hline international journal of children spirituality & 1 & Q1 \\
\hline The Journal of Happiness \& Well-Being & 1 & Q2 \\
\hline Applied computing and informatics & 1 & Q1 \\
\hline Journal of multilingual and multicultural development & 1 & Q1 \\
\hline Journal of Israeli History & 1 & Q3 \\
\hline American Ethnologist & 1 & Q1 \\
\hline Asian anthropology & 1 & Q3 \\
\hline Cogent engineering & 1 & Q2 \\
\hline $\begin{array}{l}\text { International Journal of Emerging Technology and Advanced } \\
\text { Engineering }\end{array}$ & 1 & Q1 \\
\hline Tourism Geographies & 1 & Q1 \\
\hline Ethnicities & 1 & Q1 \\
\hline Numen & 1 & Q1 \\
\hline
\end{tabular}

*Impact factor based on JCR

Table 4

Summary of systematic literature review findings

\begin{tabular}{|l|l|}
\hline Research Paradigm & Number \\
\hline Qualitative & 27 \\
\hline Quantitative & 20 \\
\hline Others (mixed, observation) & 1 \\
\hline & \\
\hline Sample Size & \\
\hline$<100$ & 17 \\
\hline $100-499$ & 5 \\
\hline$>500$ & 7 \\
\hline & \\
\hline Method of analysis & 18 \\
\hline Interviews & 14 \\
\hline survey/questionnaire & 14 \\
\hline Mixed method/secondary data & \\
\hline \multicolumn{2}{|l}{} \\
\hline Geographical locations & 25 \\
\hline Middle east & \multicolumn{2}{|l|}{} \\
\hline
\end{tabular}


INTERNATIONAL JOURNAL OF ACADEMIC RESEARCH IN BUSINESS AND SOCIAL SCIENCES Vol. 11, No. 10, 2021, E-ISSN: 2222-6990 @ 2021 HRMARS

\begin{tabular}{|l|l|}
\hline Malaysia & 6 \\
\hline Indonesia & 3 \\
\hline European & 4 \\
\hline USA & 1 \\
\hline Bangladesh & 1 \\
\hline Turkey & 1 \\
\hline Africa & 1 \\
\hline Others & 4 \\
\hline & \\
\hline Subjects on investigation & \\
\hline Islamic pilgrimage & 38 \\
\hline Satisfaction & 7 \\
\hline Loyalty & 4 \\
\hline Service & 6 \\
\hline Motivation & 6 \\
\hline Marketing & 4 \\
\hline Health & 5 \\
\hline Others & 21 \\
\hline
\end{tabular}

\section{Discussion}

In summary, the during and post-pandemic articles were still limited in both qualitative and quantitative study. Based on patterns observed from the review, recommendations are provided for future research.

\section{Attending Islamic Pilgrimage as Devotion to God}

A large number of studies have focused on the Middle East tourist experience. The investigation has been apparent where Islamic pilgrimage has flourished throughout the years as the demand has increased. As far as motivation during and post-pandemic is concerned, further studies from non-Middle East needed to be done as the Middle East sample and the non-Middle East sample is different. Hench, future research is encouraged to explore nonMiddle East Islamic pilgrimage tourists from diverse cultural backgrounds during and postpandemic new norms. A new research approach that focuses on during and post-pandemic new norms may provide a new lens towards the investigation of travel risks among nonMiddle East tourists.

\section{During and Post-Pandemic Pilgrimage}

Almost $75 \%$ of the research concerned have favoured a qualitative approach in measuring the Islamic pilgrimage tourist experience. Out of 22 studies have employed quantitative method and the most quantitative method employed to survey and questionnaire. As a result, the existing study has provided limited understanding in relation to how Islamic pilgrimage demand increase/decrease during and post-pandemic on highly contagious respiratory disease. 


\section{Deepening Theoretical Understanding}

Only one study addresses the Covid-19 situation as the main subject of investigation, while, other 48 studies reviewed only investigated Islamic pilgrimage experience. In fact, the health risk is the most research risk in Islamic pilgrimage but Covid-19 studies are still lacking. Islamic pilgrimage tourist is closely connected, but post-pandemic studies should not be limited to motivation, there is more to explore in relation to health risk. Furthermore, only one study included Covid-19, three studies another health risk, while the motivation for Islamic pilgrimage in attending Umrah and Hajj during and post-pandemic is still underexplored especially in high indexed journal.

While there are 49 studies reviewed that have investigated travelling Islamic pilgrimage to a certain extent, only one study addresses the Covid-19 situation as the main subject of investigation. In fact, tourist behaviour was the most prevalent topic as far as motivation is concerned, which has also been reflected in types of crisis studies, specifically, health risk which has emerged as the most research risk typology but Covid-19 studies are still lacking. Islamic pilgrimage tourist is closely connected, but post-pandemic studies should not be limited to motivation, there is more to explore in relation to health risk. Furthermore, only one study included Covid-19, three studies another health risk, while the motivation for Islamic pilgrimage in attending Umrah and Hajj during and post-pandemic is still underexplored especially in a high indexed journal. It is important to tap into motivation, crisis, and tourist behaviour to widening and deepening the literature understanding. It is possible for literature to explore motivation and travel behaviour in the midst and postpandemic travel. About one-third of the papers have engaged in theoretical discussion, but most of the frameworks used have not directly involved the conceptualization of motivation and crisis. Most notably, only three papers have employed health risk and one paper employed current pandemic remains at a surface level. An investigation into the theoretical construction of motivation and the Covid-19 pandemic is highly warranted to deepen the existing understanding of the topic.

Research gaps in this review are identified. This systematic literature review provides a deeper understanding of existing Islamic research and pandemic superficially with limited theoretical foundations and critically discussion dedicated to the in-depth understanding of the two concepts and the intertwined relationship between them. These recommendations together with the well- and under-researched domains are illustrated in (Fig 1) which contrast with (Fig 3) hence highlighting the contribution of this review work.

\section{Conclusion}

A systematic literature review was done on Islamic pilgrimage published in the leading journals between 2000-2021. According to our recent search for Islamic pilgrimage systematic literature review, this is the second attempt undertaken in the search of Islamic pilgrimage tourism to systematise existing research. The analysis in this study only includes high-impact journals. However, Islamic pilgrimage tourism in the leading journal remains weak. The current literature review revealed, most published articles in leading journals only focus on the receiving side of the market which are the consumers, rather than the providers. Also, keyword searches such as Islamic pilgrimage and Islamic religious tourism is still lacking in uniformity and databases. The search for Islamic tourism may produce countless pure science research results such as medicinal and engineering scope but only a few of which will be 
directly related to Islamic pilgrimage specifically on social science research. Initial search confusions are confirming that the lack of consensus on terminology. This also means that there is a strong need to conceptualise appropriate terminologies for social science research in the future.

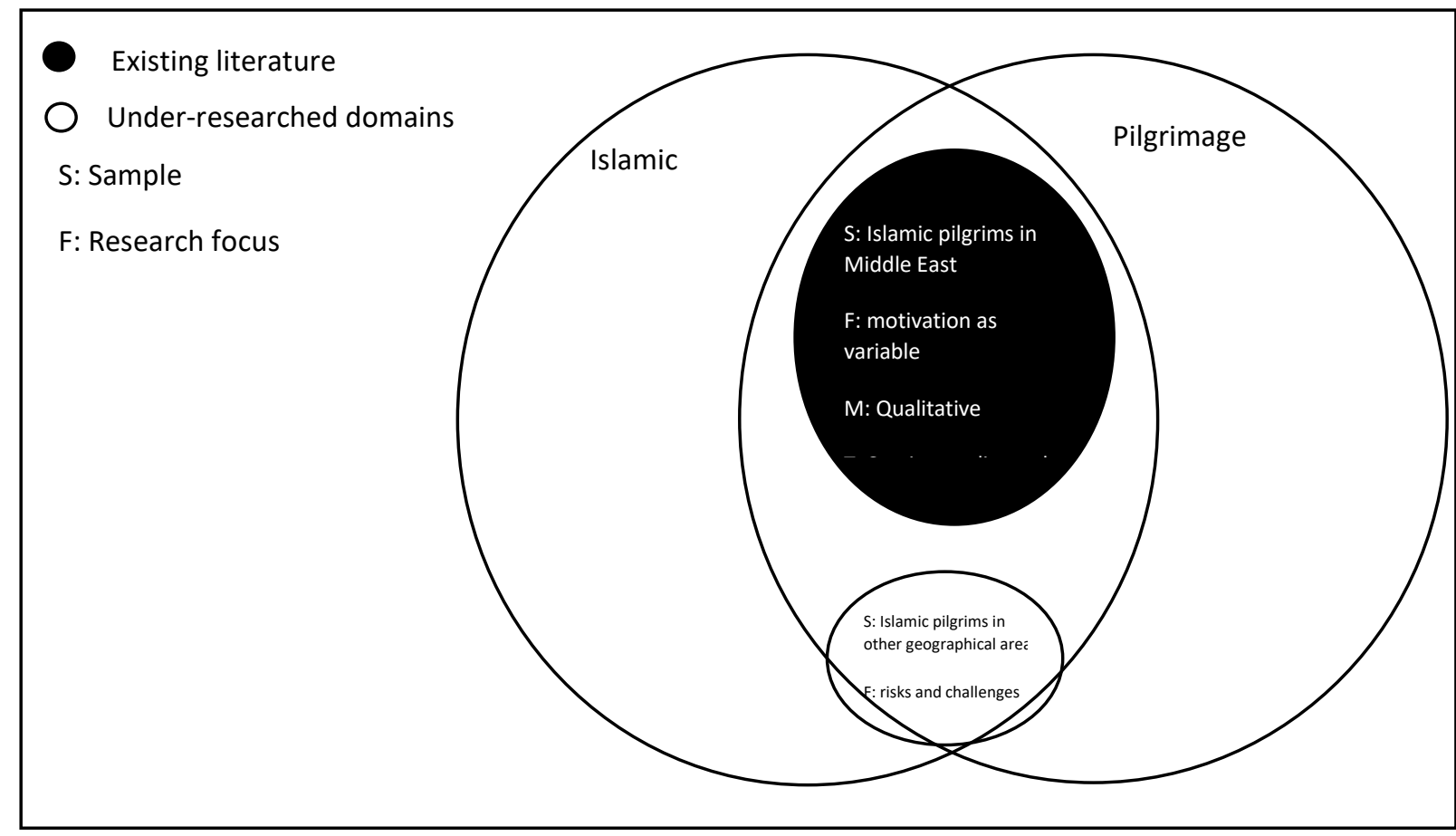

Fig 3: Mapping under-researched domains for future tourism research in Islamic pilgrimage and pandemic

The systematic literature review findings zoom into Islamic pilgrimage tourism, with effects demographically and geographically. Based on our analysis, it is confirming the connection between Islamic pilgrimage and tourism reveal a unique religious experience in the holy atmosphere with the respect to God. Considering the findings in our sample, it is possible to agree that increasing Islamic visitors to pilgrimage sites influence the economy and religious marketers.

As a policy implication, Muslim pilgrims are highly motivated to go for Islamic pilgrimage which led marketers to develop a suitable tourism product for Muslim pilgrims. Muslim pilgrims attend Islamic Hajj and Umrah pilgrimage for self-reflection and expression. Marketing and service quality has a significant impact on Muslim pilgrims both directly and indirectly. There are challenges to maintain service quality and relationships with Islamic customers. Differences in geographical, ethnic group, high vs low-income earner, lifestyle, and personal choices have different expectations from the marketers. The findings reveal challenges for Islamic religious marketer's face in Islamic pilgrimage.

Finally, the articles in the sample revealed Islamic pilgrimage is a highly demanding type of tourism and received a growing number of visitors over the years. Studies point to several systematic differences between other types of tourism and Islamic pilgrimage. None of the Islamic commercial organisations needs to undertake advertisement activities as there is already evidence of readily motivated immense demand. Islamic pilgrimage was an organized 
way of pray, travel and tourism. Consequently, this systematic literature review may be seen as an attempt to understand the unique aspects of Islamic pilgrimage.

\section{Study Contribution}

This review aimed to present a systematic literature review of past literature from the highimpact journal on Islamic tourism study. The findings from this review have indicated that the market demand for Islamic tourism has increased, and there is an evident need to study tourist behaviour, attitude, and expectations after the Covid-19 pandemic to practical outcomes that would be beneficial to Umrah tour operators. Specifically, this review has shown that existing studies on Islamic religious tourism research are focused on these two main areas: 1) service quality of Islamic religious tourism and 2) Islamic tourist motivation. This review indicates that the benefits of Islamic tourists have implications for tourism marketing.

\section{Theoretical Implications}

Theoretical implications were analysed for further development in the research field. There are only ten studies in a high ranked journal that published between 2000-2021 five of the journals come from Q1 impact factor which are Tourism Management Perspective, Journal of Travel and Tourism Marketing, International Journal of Religious Tourism and Pilgrimage that directed to Islamic pilgrimage, which shows that Islamic articles can be written submit and publish in high-ranked journals. Therefore, the chief editors can consider publishing to these high-ranked journals. The possibility of losing a good percentage of their readership will be high if the submitters avoid this high-impact journal. 'Islamic pilgrimage' terms are also important as they should be uniformly used to avoid confusion across journals.

This study is strongly encouraging researchers to publish in the high-ranked journal of Islamic tourism, religious tourism, and any social science-related tourism. Due to prejudice among researchers on high-impact journals, most top-ranked journals do not publish religious studies. Therefore, the current study addressed the issue to encourage researchers in Islamic religious tourism to publish their findings of this study in the top-ranked journals.

This systematic literature review has stocktake on relevant publications in Islamic religious tourism and Islamic pilgrimage from high-impact journals may guide the future researcher to publish more impactful studies. A high-impact journal is the main source of information for researchers and readers from all around the globe which will find this study useful as the publications in these journals remain deficient.

\section{Limitations}

There are limitations to this study. Only high-ranked tourism journals were included in this study. Further, this study only considers articles that were written in English. Due to a large number of tourist's arrival of Islamic pilgrimage that has attracted global attention, other language studies will be an added advantage for further insights. Future research could investigate writing in other languages. Also, future research should investigate other electronic databases such as Emerald Insights should be considered in future work. Additionally, future work proposes to carry out another review of Islamic pilgrimage research using meta-analysis of published papers in these high-impact journals. Finally, there might relevant studies that we might have missed in the literature in which, might not cover the 
various field of Islamic pilgrimage. Current studies on a collected sample of the article are relevant to the objectives which can be conclusive and generalizable.

\section{References}

Heidari, A., Yazdani, H. R., Saghafi, F., \& Jalilvand, M. R. (2018). The perspective of religious and spiritual tourism research: a systematic mapping study. Journal of Islamic Marketing, 9(4), 747-798. https://doi.org/10.1108/JIMA-02-2017-0015

Ritonga, H. M. (2018). Rural tourism marketing strategy and swot analysis: A case study of bandar pasir mandoge sub-district in north sumatera. Retrieved March 14, 2021, from https://www.researchgate.net/publication/328552386_Rural_tourism_marketing_stra tegy_and_swot_analysis_A_case_study_of_bandar_pasir_mandoge_subdistrict_in_north_sumatera

Kitchenham, B., Brereton, P. O., Budgen, D., Turner, M., Bailey, J., \& Linkman, S. (2008). Systematic literature reviews in software engineering - A systematic literature review. Information and Software Technology, 51, 7-15. https://doi.org/10.1016/j.infsof.2008.09.009

Madalina Lavinia Tala. (2018). Dimensions of religious tourism. Retrieved March 14, 2021, from

https://www.researchgate.net/publication/233752241_Dimensions_of_religious_touri sm

Qurashi, J. (2017). Commodification of islamic religious tourism: From spiritual to touristic experience. International Journal of Religious Tourism and Pilgrimage, 5(1), 89-104. https://doi.org/10.21427/D7JX40

Rinschede, G. (1992). Forms of religious tourism. Annals of Tourism Research, 19(1), 51-67. https://doi.org/10.1016/0160-7383(92)90106-Y

United World Tourism Organization. (2011). Religious Tourism in Asia and the Pacific. In Religious Tourism in Asia and the Pacific. https://doi.org/10.18111/9789284413805 